\title{
Chondrichthyans from the Lower Permian of Mechetlino, South Urals, Russia
}

\author{
ALEXANDER O. IVANOV
}

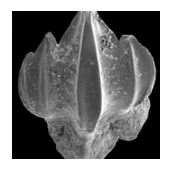

\begin{abstract}
A chondrichthyan assemblage is described from the Early Permian (Artinskian and Kungurian) of Mechetlino Quarry (Bashkortostan, South Urals). The assemblage includes the teeth of a symmoriiform, a sphenacanthid euselachian and an anachronistid neoselachian, as well as various denticles and scales. The dentition of Cobelodus aculeatus has been restudied. The teeth of a new genus of symmoriiform shark are described as Kungurodus, the internal structure of which is reconstructed using microtomography. $•$ Key words: Early Permian, chondrichthyans, Urals.
\end{abstract}

IVANOV, A.O. 2016. Chondrithyans from the Lower Permian of Mechetlino, South Urals. Bulletin of Geosciences 91(4), 717-729 (5 figures). Czech Geological Survey, Prague. ISSN 1214-1119. Manuscript received November 2, 2016; accepted in revised form December 20, 2016; published online February 6, 2017; issued February 7, 2017.

Alexander O. Ivanov, Institute of Earth Sciences, St. Petersburg State University, Universitetskaya nab. 7-9, St. Petersburg, 199034 Russia; IvanovA-Paleo@yandex.ru•Kazan' Federal University, Kremlyovskaya ul. 18, Kazan', 420008 Russia

An assemblage of chondrichthyan fishes has been found in the Artinskian-Kungurian of Mechetlino Quarry. The Mechetlino section, a candidate section of the Global Section Stratotype and Point (GSSP) for the base of the Kungurian Stage, is located on the right bank of the Yuryuzan River, near the eastern border of Mechetlino village, in the northeastern part of Bashkortostan, on the western slopes of the South Urals, Russia (Fig. 1A-C). Mechetlino Quarry is located about $600 \mathrm{~m}$ east of the Mechetlino Stratotype section. Data on the lithology, distribution of conodonts and other fossils in both sections has been presented by Chernykh and Chuvashov in several papers (Chuvashov \& Chernykh 2011, Chernykh et al. 2012, Chernykh et al. 2015). The deposits of the Artinskian Saranian Regional Stage and the Kungurian Sargian Regional Stage are represented by sandy and carbonate sediments, such as marls, limestones, mudstones, and sandstones with thin layers of volcanic tuff (Chernykh et al. 2015). The deposits contain a diverse range of fossils: fusulinids, smaller foraminifers, ostracods, ammonoids, bryozoans, crinoids, conodonts, calcareous algae, plant remains (Chuvashov \& Chernykh 2011) and fishes (Ivanov 2012a). The most significant taxa found there, among others, are the conodonts Neostreptognathodus labialis Chernykh, N. lectulus Chernykh, N. pequopensis Behnken, N. pnevi Kozur \& Movshovitsch, N. pseudoclinei Kozur \& Movshovitsch, N. ruzhencevi Kozur, and Sweetognathus somniculosus Chernykh; the ammonoids Paragastrioceras verneili (Ruzhencev), P. karpinski (Ruzhencev), Uraloceras cf. U. bogoslovskayae
(Voronov), U. tchuvashovi Bogoslovskaya, and U. fedorovi (Karpinsky) (Chernykh et al. 2015). The presence of $N$. pnevi marks the base of the Kungurian Stage.

The chondrichthyan microremains recovered from Mechetlino Quarry occur at three levels in the Artinskian succession and in three levels of the Kungurian (Fig. 1D). The fish microremains were extracted from conodont residues obtained by standard processing of carbonate layer samples by formic acid treatment. The chondrichthyan microremains described herein are represented by isolated teeth of the symmoriiform Kungurodus obliquus (Ivanov), the sphenacanthid euselachian Sphenacanthus sp. and the anachronistid neoselachian Cooleyella amazonensis Duffin, Richter \& Neis, in addition to a cephalic spine, diverse scales and denticles. K. obliquus was formerly described from the Asselian-Artinskian of the South Urals by the present author as a new species of the genus Cobelodus (Ivanov 2005). This genus was previously known from the Pennsylvanian of USA (Zangerl \& Case 1976). A detailed re-examination of the dentition in the specimens of Cobelodus aculeatus (Cope) from the Pennsylvanian black shales of the North American Midcontinent indicates that the teeth from the Early Permian of the South Urals are quite different from those of Cobelodus and are consequently assigned to a new genus established here.

The micrography of the specimens was carried out using scanning electron microscopes Cambridge CamScan-4 and Tescan VEGA-II XMU. Some specimens of Cobelodus aculeatus were photographed using an optical microscope 


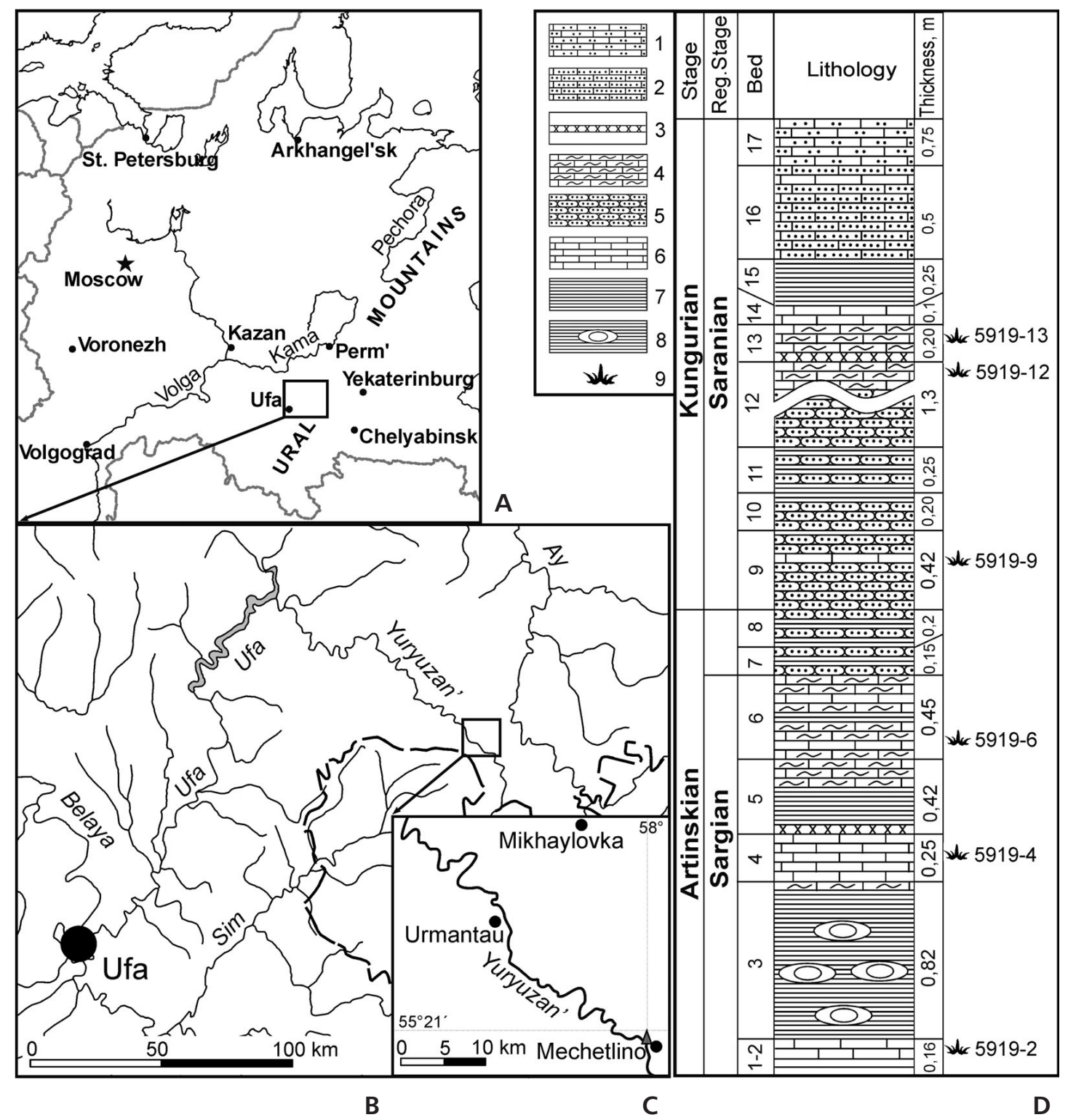

Figure 1. A-C - maps showing the location of Mechetlino Quarry (C after Chernykh et al. 2012). D - stratigraphical column of the Mechetlino Quarry demonstrating the distribution of samples with chondrichthyan remains (column after Chernykh et al. 2012). Legend: 1 - calcareous sandstones, 2 - arenaceous limestones, 3 - tuff, 4 - marls, 5 - sandstones, 6 - limestones, 7 - mudstones, 8 - mudstones whit argillo-calcareous nodules, 9 - chondrichthyan remains.

Leica MZ 16 fitted with a digital camera. The internal structure of Kungurodus teeth was reconstructed using microtomography - a Bruker SkyScan 1172 (Center for Geo-Environmental Research and Modeling "GEOMODEL", Research park of St. Petersburg State University). The virtual cross section images were generated from the $3 \mathrm{D}$ reconstructions using the following software - DataViewer, CTAn and CTvox.

The specimens described here from Mechetlino Quarry are housed in the Palaeontological Museum of the Institute of Earth Sciences, St. Petersburg State University (abbreviation PM SPU), under collection No. 76. Institutional ab- breviations of additional museum collections of Cobelodus aculeatus are as follows: FNMH - Field Museum of Natural History (Chicago, USA); SMF - Senckenberg Research Institute and Natural History Museum (Frankfurt am Main, Germany); SMNH - Swedish Museum of Natural History (Stockholm, Sweden).

\section{Dentition of Cobelodus}

Although the skeleton of Cobelodus aculeatus (Cope) has been studied in detail (Zangerl \& Case 1976), the teeth are 


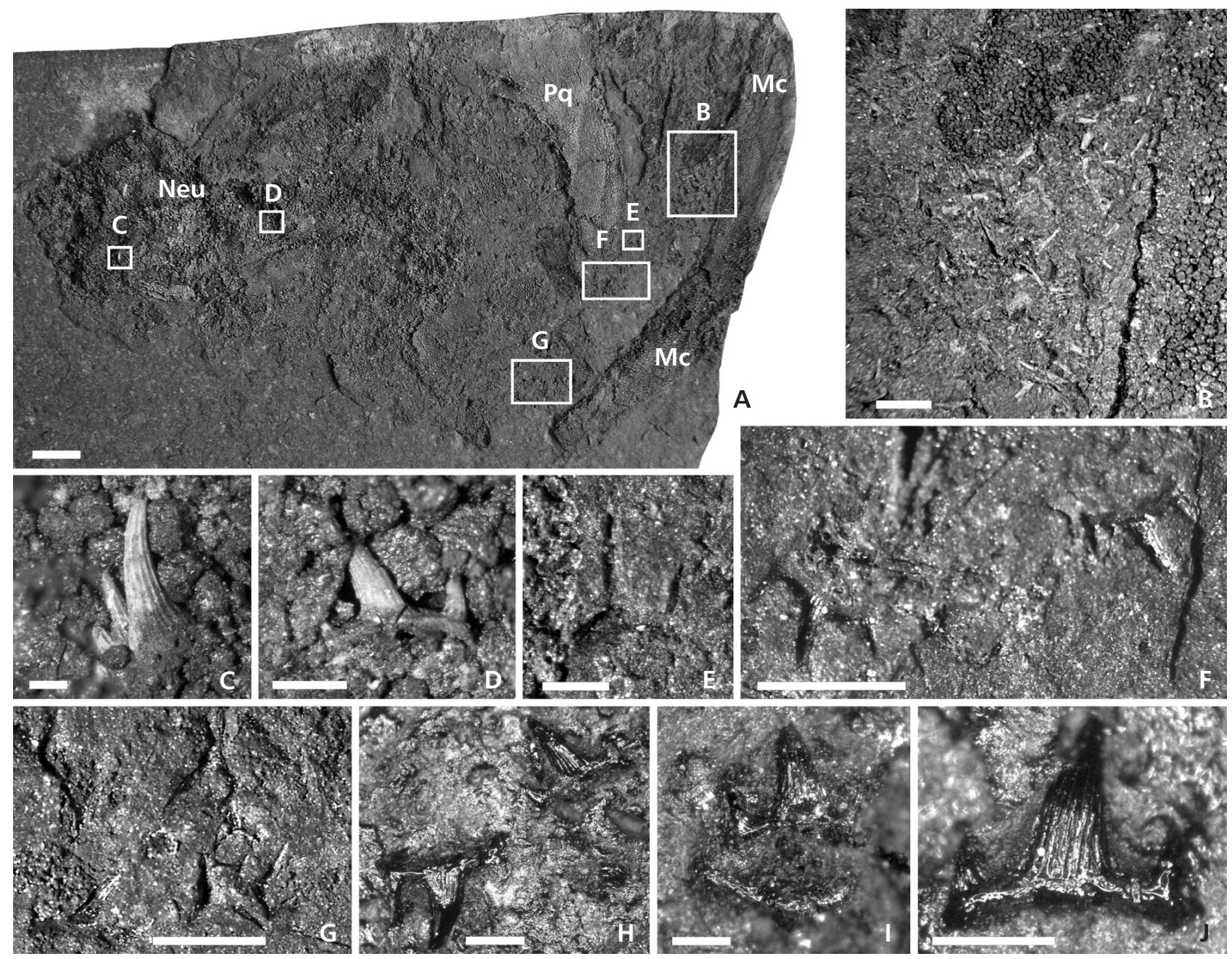

Figure 2. Cobelodus aculeatus (Cope, 1894), Excello Shales, Desmoinesian, Middle Pennsylvanian, Bethel Quarry, Pike County, Indiana, USA. - A-G - disarticulated skull, SMNH P00011607, white rectangles show the position of detailed photographs (B-G); B - concentration of monocuspid denticles; C - isolated buccopharyngeal denticle ("Stemmatias"-type), lateral view; D - isolated tooth, labial view; E - isolated tooth, lingual view; F, G - several isolated teeth. $\bullet \mathrm{H}-\mathrm{J}$ - isolated teeth in the shale block with part of disarticulated skeleton, SMF P 7345a; H - two isolated teeth, labial views; I - two isolated teeth, labial and linguo-basal views; J - isolated teeth, labial view. Photographs from the optical microscope. Abbreviations: Mc - Meckel's cartilage, Neu - neurocranium, Pq - palatoquadrate. Scale bars: A - 5mm; B, F, G - 1 mm; C-E, H-J - $100 \mu \mathrm{m}$.

poorly known. Cope (1894) described Styptobasis aculeata Cope from the Pennsylvanian black shales of Illinois, USA based on one partial skeleton. He illustrated the fragment of a tricuspid tooth (Cope 1894; pl. XX, fig. 3) as well as the monocuspid denticles, which he also identified as teeth (Cope 1894; pl. XX, fig. 4, 5). Zangerl (1973) noted that the type species of Styptobasis, S. knightiana Cope, and $S$. aculeata should be attributed to different genera and established the new genus Cobelodus to embrace them. Zangerl and Case (1976) described in detail the numerous specimens of Cobelodus aculeatus (Cope) from the various localities of the Pennsylvanian Mecca fauna of the North American Midcontinent. They suggested that the lower jaws bear the tricuspid cladodont teeth but that the long monocuspid "teeth" were placed on the palatoquadrate. The authors provided drawings of several teeth and re- marked on only a few features of the tricuspid teeth such as the separated cusps, the slender asymmetry of the crown, and the saddle-shaped base with a narrow lingual torus. $\mathrm{Zi}$ dek (1992) studied new specimens of symmoriid skeletons from the Pennsylvanian Wild Cow Formation of Kinney Quarry, New Mexico and referred them to C. aculeatus. Later, Maisey (2007) revised the morphology of symmoriiform braincases and concluded that the New Mexico specimens could be distinguished from $C$. aculeatus and should be referred to a different genus.

The specimens of $C$. aculeatus from the collections of Field Museum of Natural History (Chicago, USA), Senckenberg Research Institute and Natural History $\mathrm{Mu}-$ seum (Frankfurt am Main, Germany) and Swedish Museum of Natural History (Stockholm, Sweden) were studied by the present author. These specimens are blocks of 

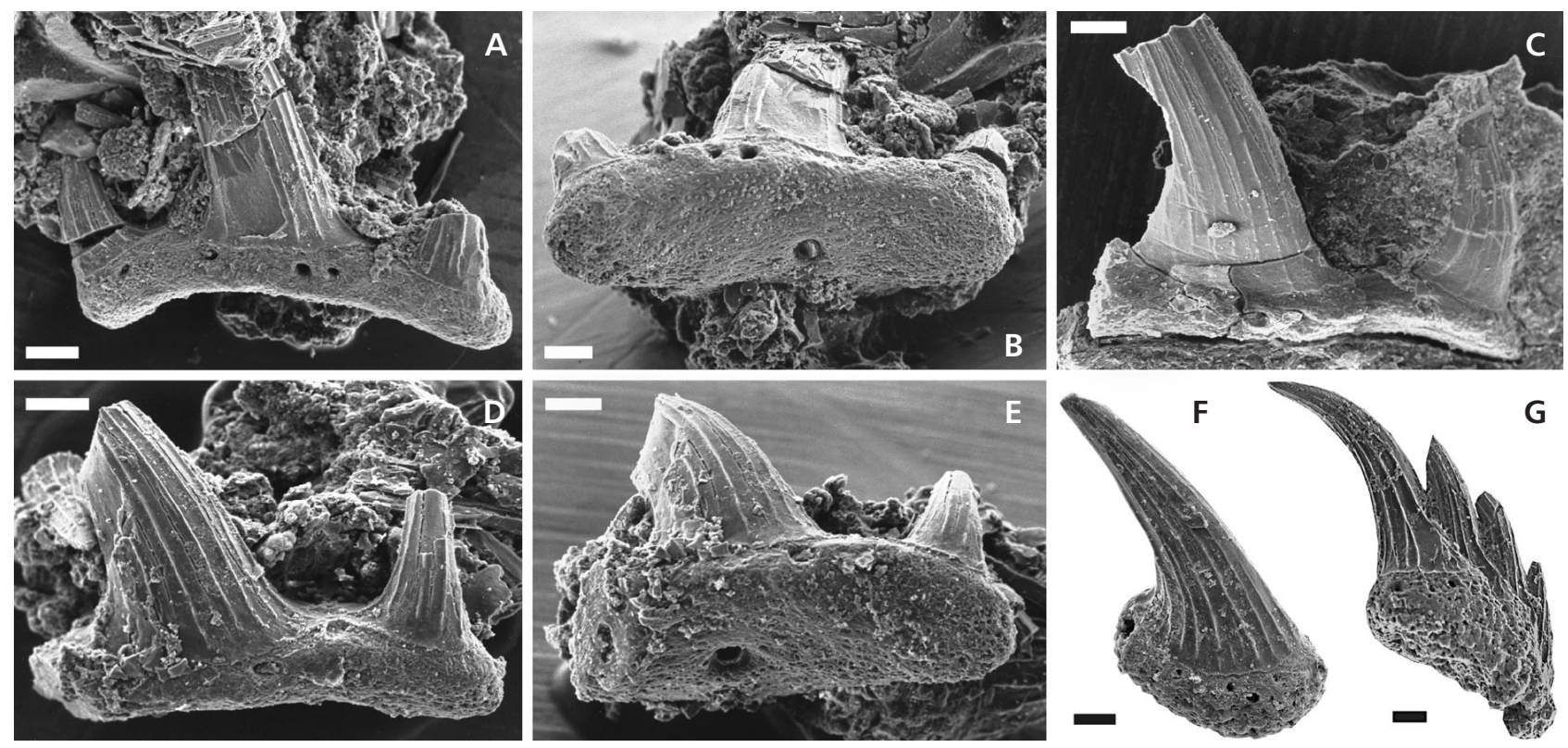

G

Figure 3. Cobelodus aculeatus (Cope, 1894), FNMH PF 2727, Excello Shales, Desmoinesian, Pennsylvanian, Bethel Quarry, Pike County, Indiana, USA. • A-E - isolated teeth; A, C, D - labial and B, E - oblique basal views. $\bullet$ F - monocuspid denticle, oblique lateral view. $\bullet$ G - buccopharyngeal denticle ("Stemmatias"-type), lateral view. SEM pictures. Scale bars $-100 \mu \mathrm{m}$.

black shales containing different parts of the skeleton of Cobelodus (Figs 2, 3). All of the examined jaws lack teeth, but isolated cladodont teeth and some denticles are spread on the shale surface adjacent to the jaw cartilages. The denticles include multicuspid and monocuspid morphotypes. The multicuspid denticles of "Stemmatias"-type have a crown with striated, conical cusps arranged in a single spiral row and surmounting a curved base (Figs 2C, $3 \mathrm{G})$. The cusps consecutively overlap each other and increase in size posteriorly. The number of cusps varies from two to six, but is most commonly four or five. Denticles of this morphotype are known from the buccopharyngeal region in several genera of symmoriiforms such as Cobelodus (Zangerl \& Case 1976), Stethacanthus (Williams 1985, Coates \& Sequeira 2001), Stethacanthulus and Symmorium (Williams 1985). The monocuspid denticles possess a very long, spine-like crown and a small, convex basally, rounded or oval base (Fig. 3F). The crown is mainly curved and inclined posteriorly, rarely almost straight, and sometimes flattened laterally. The crown is rounded in cross section and ornamented with distinct straight cristae. The monocuspid denticles differ considerably from the dentition teeth of all known Palaeozoic elasmobranchs. They very much resemble the denticles from the cranial cap or spine-brush complex of other symmoriiforms such as Stethacanthus (Lund 1974, Coates \& Sequeira 2001), Orestiacanthus (Lund 1984), Falcatus (Lund 1985) and Damocles (Lund 1986). The monocuspid denticles considerably predominate among the cladodont teeth and buccopharyngeal denticles in all examined speci- mens of Cobelodus. They often form accumulations near cranial or visceral cartilages (Fig. 2B). These denticles are placed closely and almost parallel to each other, but the accumulations do not contain cladodont teeth. Such an accumulation was observed in most specimens, included the holotype. Cobelodus had no the spine-brush complex in contrast to symmoriiforms such as Stethacanthus, Orestiacanthus, Falcatus and Damocles. Cobelodus may have possessed a cranial cap consisting of monocuspid denticles, however. Such a cap formed by monocuspid denticles is known in the symmoriiform Stethacanthus (Lund 1974, Zangerl 1981, Coates \& Sequeira 2001). The author of the present paper suggested in his 2004 talk at the Early/Lower Vertebrate Symposium held in Gramado, Brazil, that the monocuspid denticles are not teeth from the upper jaw, but formed a cranial cap on the dorsal surface of the head, based on his examination of the specimens. Later such an assumption was published by Maisey (2007) based on personal communication received from M. Ginter.

The teeth of $C$. aculeatus are small, ranging from 0.2 to $1.8 \mathrm{~mm}$ mesiodistally, possessing a slightly asymmetrical cladodont crown and a thin base (Figs 2D-J, 3A-E). The crown is commonly tricuspid including three main cusps: a large central cusp and two moderate lateral cusps. Occasional teeth have a pair of small intermediate cusps located between the central and lateral cusps. The crown is not consolidated: the cusps are separated from each other by wide depressions. All cusps are incurved lingually, oval in cross section and ornamented with distinct straight cristae on the labial surface. The lingual side of the cusps is covered by 
more delicate striations. The central cusp and sometimes also the lateral cusps are rather inclined mesially or distally. The lateral cusps occasionally differ in height in a single tooth. The base is oval in shape, with a short lingual extension and lacking an apical button. The labio-basal edge of the base is straight and bears several foramina for vascular canals; the lingual torus is curved in lingual view. The basal surface is smooth and slightly concave, lacking a labio-basal projection or tubercles but bearing a large foramen for a vascular canal located almost in the centre of the surface. The cusps are composed of orthodentine with a large central pulp canal, and the base contains trabecular dentine. The teeth of $C$. aculeatus show considerable variation in the inclination of the cusps, the proportions of the lateral cusps, the presence or absence of intermediate cusps and the degree of concavity of the base.

\section{Systematic palaeontology}

Class Chondrichthyes Huxley, 1880

Subclass Elasmobranchii Bonaparte, 1838

Order Symmoriiformes Zangerl, 1981

Family Incertae sedis

\section{Genus Kungurodus gen. nov.}

2005 Cobelodus Ivanov, p. 133-134.

Type species. - Cobelodus obliquus Ivanov, 2005.

Etymology. - From Kungur, the stratotype area of Kungurian deposits, and the Greek ódoú $\varsigma$ - tooth.

Diagnosis. - Small cladodont teeth with three to five incurved cusps, inclined lingually; cusps labio-lingually flattened and with lateral carinae in the upper part; central cusp slightly higher and considerably wider than the lateral cusps, dislocated labially; lateral cusps diverge strongly from the crown centre; cusp ornamentation varying from long to short cristae; thin and arched base with short lingual torus and acuminate lateral parts; single prominent apical button protruding over the lingual margin, surrounded by lingual depressions; labio-basal projection thickening at the labial edge; main canal openings located distally on the button; base vascularization system with up to two main transversal and longitudinal canals.

Remarks. - The teeth of Kungurodus differ from the teeth of other symmoriiforms in the prominent, quadrate apical button strongly protruding over the lingual margin and flanked by shallow depressions, the high lateral cusps, and from the teeth of most symmoriiform taxa, excluding $\mathrm{Co}$ - belodus, in the short lingual torus of the base. Kungurodus teeth are distinguished from the teeth of Cobelodus in the presence of the symmetrical crown, prominent apical button flanked by two lingual depressions and the presence of a labio-basal projection. The cusps of Cobelodus teeth are separated from each other. Their ornamentation includes uniform straight cristae in contrast with the compound ornamentation of Kungurodus teeth consisting of long and short, wavy or inclined cristae forming a lanceolate pattern. The teeth of Denaea differ from the described teeth here in possessing lateral cusps, which are shorter than the central cusp; a lingually extended base with pointed lingual rim; a rounded apical button and labio-basal tubercle.

Occurrence. - Early Permian; South Urals, Russia and Cisurals, Kazakhstan.

\section{Kungurodus obliquus (Ivanov, 2005)} Figure 4

2005 Cobelodus obliquus sp. nov.; Ivanov, p. 133-134, fig. 2a-1.

2009 Cobelodus obliquus, Ivanov 2005. - Lebedev, fig. $4 \mathrm{k}-\mathrm{m}$.

Material. - Five isolated teeth from sample 5919-2b and two teeth from sample 5919-4b, Artinskian, Sargian Regional Stage; one tooth from sample 5919-9a, Kungurian, Saranian Regional Stage, Mechetlino Quarry. Additional 42 isolated teeth: the Asselian, Kholodnologian Regional Stage, section 2018, Ural River, right bank, near Nikol'skoe village; Sakmarian, Tastubian Regional Stage, section 1507, road cut of Chulpan - Mesyagutovo, near Maloyaz; the Sakmarian, Sterlitamakian Regional Stage, section 962, road cut of Ufa - Chelyabinsk, 1 km from Sim town in the direction of Chelyabinsk; Artinskian, Burtsevian and Irginian Regional Stage, section 1070, Dal'niy Tyul'kas Creek, southward from Krasnousol'sk; Artinskian, Sargian Regional Stage, section 1629, Belaya River, near Sterlitamak, 300 m northward from Tra-Tau Hill.

Description. - The teeth of Kungurodus are small; the sizes of the tooth base range from 0.7 to $2.6 \mathrm{~mm}$ mesiodistally. They possess a cladodont crown including three to five cusps. The main central and lateral cusps are all high. The central cusp is slightly higher and considerably wider than the lateral ones. The lateral cusps are dislocated labially. The cusps are incurved and inclined lingually, with the curvature of the lateral cusps being more marked than that of the central one. All of the cusps are slightly labio-lingually flattened distally and rounded in cross section at the base. The lateral cusps strongly diverge from the crown centre. The cusps are connected between each other only at their 
bases. The intermediate cusps vary from small to quite high reaching the half of the height of central cusp (Ivanov 2005, fig. 2a-f). They are more labially displaced than the lateral cusps. The bases of all cusps in the five-cusped teeth are arranged in a curved line. The tricuspid teeth have a pronounced lateral carina in the upper part of central cusp, which can sometimes be weakly traced in lateral cusps. The five-cusped teeth possess well-developed carinae on all cusps (Ivanov 2005, fig. 2a, b, d, e). Both lingual and labial faces of the cusps are ornamented with the distinct long and short cristae. The latter run from the cusp base on the lingual side, but do not reach the crown/base boundary labially. The labial face of the central cusp bears up to 9 long cristae, with the lingual surface bearing up to 7 . The lateral cusps are ornamented with 3 to 6 long cristae. The cristae are straight, slightly wavy or incurved at the apex. Two long cristae frequently unite to form nested inverted ' $V$ '-shapes (lanceolate structure) on the labial side of the main cusp. Some cristae show branching at the cusp base. The crown forms an obtuse angle with the base. The boundary between the crown and the base is distinct and marked by a shallow groove on the labial side of the tooth.

The base is thin and arched mesiodistally, almost triangular or rhomboid in shape, and has a short lingual extension, is acuminate laterally and quite prominent behind the crown/base boundary, sloping occlusally and concave basally. The apical button is robust, quadrate or rarely rectangular, located at the lingual rim where it protrudes strongly over the lingual edge, separated by shallow depressions on both sides and by a weakly developed groove from the central cusp. The button compounds the compact tissue but the surface of the depression is considerably porous with minute papillae (Fig. 4I). The labio-basal projection thickens at labial edge and fades with the basal surface without distinct margins. The projection is more developed in tricuspid teeth. The base of five-cusped teeth is more arched, has the same thickness as the almost straight lingual edge. Their apical button is less prominent. Some five-cusped teeth possess lingual notches separating the apical button (Fig. 4O).

The cusps comprise orthodentine with slightly branched dentine tubules, while the base is composed of trabecular dentine. One or two foramina of the main vascular canal open on lingual edge of the button often displaced from the midline. The canal is frequently traced on the basal side as a groove forming a small notch on the lingual edge of the button. Two foramina are placed in the labial groove on both sides of labio-basal projection. An additional foramen is occasionally observed in the groove between the button and central cusp (Fig. 4A). The vascularization system of all the teeth includes one or two transverse, large, main, longitudinal and small secondary and pulp canals (Fig. 4L, $\mathrm{M}, \mathrm{P}-\mathrm{R})$. The main canals penetrate the greater part of the base under the button, from the lingual rim to the longitudinal canal. The latter connects the pulp canals of all cusps, running along the crown and continuing to the lateral parts of the base. The tricuspid teeth possess a more simply arranged vascularization system (Fig. 4L, M). Several secondary canals are restricted to the central part of the base, near the connection of the main and longitudinal canals. The latter has no ramification. The pulp canal is extended in the middle part of the central cusp. The vascularization system of five-cusped teeth is more compound (Fig. 4P-R). The numerous secondary canals fill out the base under the apical button and the crown. The longitudinal canal bears short ramifications, which run to some of the ascending canals and continue to the pulp canal.

Remarks. - The teeth of Kungurodus from Mechetlino Quarry are only tricuspid. The tricuspid teeth dominate collections from other localities of the South Urals (Ivanov 2005). The five-cusped teeth are quite scarce, and have been found in the Artinskian of the Kazakhstanian Cisurals (Lebedev 2009).

Occurrence. - Early Permian, Asselian-Kungurian; South Urals, Russia; Artinskian, Cisurals, Kazakhstan.

Cohort Euselachii Hay, 1902

Order Incertae sedis

Family Sphenacanthidae Maisey, 1982

Figure 4. Kungurodus obliquus (Ivanov, 2005), teeth. • A-N - Early Permian, Artinskian, Sargian Regional Stage (Figs A-E, G-N) and Kungurian, Saranian Regional Stage (Fig. F), South Urals, Bashkortostan, Mechetlino Quarry; A-C - PM SPU 76-1, sample 5919-2b, A - occlusal, B - lingual and C - oblique lateral views; D, E - PM SPU 76-2, sample 5919-2b, D - oblique labial and E - oblique basal views; F - PM SPU 76-3, sample 5919-4b, oblique labial view; G-I - PM SPU 76-4, sample 5919-2b, G - labial and H - occlusal views, I - detail of the base; J-M - PM SPU 76-5, sample 5919-2b, $\mathrm{J}$ - lingual and $\mathrm{K}$ - basal views, $\mathrm{L}, \mathrm{M}$ - microtomographic images of tooth, $\mathrm{L}$ - cross-section of tooth crown, M - cross-section of tooth base; $\mathrm{N}$ - PM SPU 76-6, sample 5919-9a, labial view. • O-R - PM SPU 76-7, Early Permian, Sakmarian, Sterlitamakian Regional Stage, South Urals, Chelyabinsk Region, road cut of Ufa - Chelyabinsk motorway, section 962; O - occlusal view; P-R - microtomographic images of tooth; P - oblique lingual view with transparent dental tissue; Q - cross-section of tooth base; R - cross-section of tooth crown. Abbreviations: avc - ascending vascular canal, fvc - foramen of vascular canal, lvc - longitudinal vascular canal, mvc - main vascular canal, pc - pulp canal, svc - secondary vascular canal. Scale bars: A-H, J-N $100 \mu \mathrm{m}$; I - $20 \mu \mathrm{m}$; O-R - $700 \mu \mathrm{m}$. 


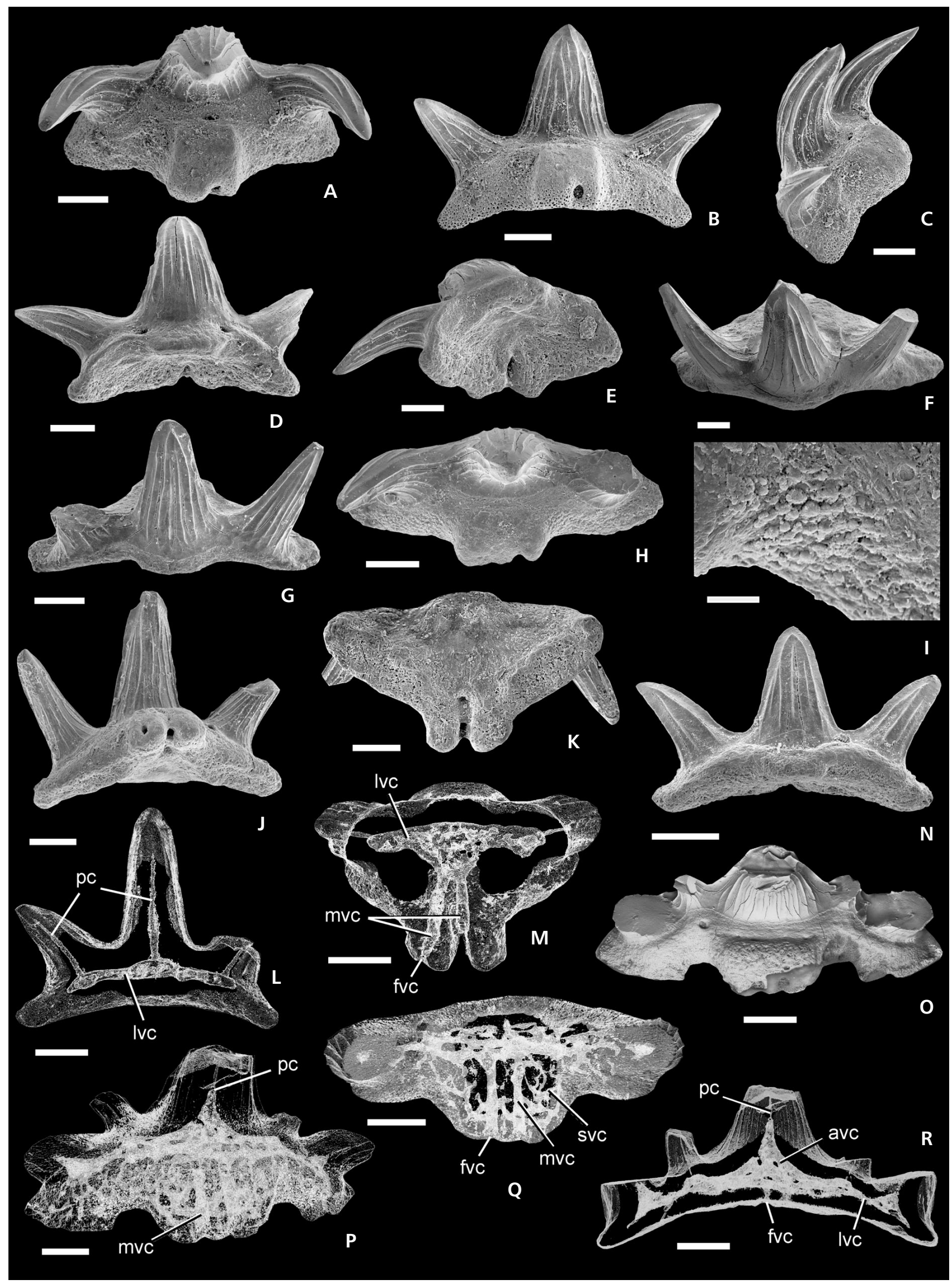




\section{Genus Sphenacanthus Agassiz, 1837 (in 1843)}

\section{Sphenacanthus sp.}

Figure 5A-C

Material. - One incomplete tooth, sample 5919-4b, Artinskian, Sargian Regional Stage; Mechetlino Quarry.

Description. - The tooth has a pyramidal protacrodont crown, which is slightly flattened labio-lingually. The five conical cusps are straight, oval in cross section, fused for most of their height and separated by a shallow depression at the apex of the cusp. The cusps are gradually arranged from the high and wide central cusp to small lateral cusps mesially and distally. The cusps are covered by coarse, straight vertical ridges on all of the surfaces, diverging basally from the cusp tip. The preserved fragment indicates that the tooth base is extended lingually, and perforated by numerous foramina of large vascular canals forming a horizontal row.

Remarks. - The tooth described here most closely resembles the teeth of Sphenacanthus delepinei Fournier \& Pruvost known from the Early Viséan locality of Denée, Belgium (Fournier \& Pruvost 1928, Ivanov \& Derycke 2005). The Denee specimen contains the palatoquadrate, Meckel's cartilage, isolated tooth families and a few teeth. The tooth crowns of $S$. delepinei, by comparison, contain 6 to 8 cusps. The teeth of Sphenacanthus carbonarius (Giebel) (Soler-Gijón 1997) and S. serrulatus Agassiz (Dick 1998) are distinguished from the tooth described here in higher central cusp, rounded cusps in the cross section and numerous ridges on all of the crown surfaces.

Subcohort Neoselachii Compagno, 1977

Order Incertae sedis

Family Anachronistidae Duffin \& Ward, 1983

\section{Genus Cooleyella Gunnell, 1933}

Type species. - Cooleyella peculiaris Gunnell, 1933.
Other species. - Cooleyella amazonensis Duffin, Richter \& Neis, 1996; C. duffini Ivanov, 2015 (Ivanov et al. 2015); C. fordi (Duffin \& Ward, 1983).

\section{Cooleyella amazonensis Duffin, Richter \& Neis, 1996 Figure 5D-I}

Material. - Three isolated teeth from sample 5919-4b, Artinskian, Sargian Regional Stage, Mechetlino Quarry.

Description. - The small teeth of this anachronistid shark vary from 0.3 to $0.6 \mathrm{~mm}$ in mesiodistal crown length. The tooth crown is much larger than the base. The crown is smooth, isometric, and bears a distinct occlusal crest and three cusps. The crown is divided by the occlusal crest on the extended, sloping labial and the short, inclined lingual surfaces. The labial surface is trapezoid in shape, and slightly concave. The cusps are almost equal in size. The central cusp is separated from the lateral cusps by shallow depressions. The wide and straight labial flange terminates the labial surface of the crown. The crown/base junction is incised, and the crown overhangs the base.

The tooth base is oval or rounded in shape, and possesses extended, slightly convex lingual and very narrow labial faces. The lingual edge of the base is rounded. A small, circular basal tubercle is located beneath the labial flange. The basal surface is drop-like in shape, slightly convex in the lingual part, and has a narrow depression or groove surrounding the basal tubercle. The large pit of the pulp cavity opens in the depression. The main vascular canal opens in the center of the lingual rim, frequently forming a small notch.

Remarks. - The teeth of Cooleyella amazonensis are distinguished from the teeth of other species of Cooleyella in their narrow crown and base, the fact that the base is smaller than the crown, their short and wide labial flange, deeper crown/base junction, the central cusp separated from the lateral cusps by two depressions on the occlusal crest, the rounded basal tubercle, and the narrow basal groove (Duffin \& Ward 1983, Duffin et al. 1996, Ivanov 2011, Ivanov et al. 2013).

Figure 5. Chondrichthyan remains from the Early Permian, Artinskian, Sargian Regional Stage (Figs A-F, K-R, U) and Kungurian, Saranian Regional Stage (Figs. G-J, S, T), South Urals, Bashkortostan, Mechetlino Quarry. • A-C - Sphenacanthus sp., tooth, PM SPU 76-8, sample 5919-4b; A - occlusal, B - lingual and C - oblique lateral views. • D-I - Cooleyella amazonensis Duffin, Richter \& Neis, 1996, teeth, sample 5919-4b; D-F - PM SPU 76-9; D - occlusal, E - lingual and F-oblique lateral views; G-I - PM SPU 76-10; G-occlusal, H - oblique basal and I-basal views. • J - cephalic spine of possible hybodontiform, PM SPU 76-11, sample 5919-12a, oblique crown view. • K-M - denticles of symmoriiform cf. Kungurodus; K - monocuspid denticle, PM SPU 76-12, sample 5919-2b, lateral view; L - bicuspid denticle, PM SPU 76-13, sample 5919-4b, lateral view; M - buccopharyngeal denticle ("Stemmatias"-type), PM SPU 76-14, sample 5919-4b, oblique anterior view. • N-U - chondrichthyan scales; N - Scale of type 1, PM SPU 76-15, sample 5919-6a, crown view; O-Q - scales of type 2; O - two scales with partly fused bases, PM SPU 76-16, sample 5919-2b, crown view; P - scale, PM SPU 76-17, sample 5919-4b, crown view; Q - scale, PM SPU 76-18, sample 5919-4b, crown view; R - protacrodontid scale of type 3, PM SPU 76-19, sample 5919-4b, lateral view; S, T - Euselachian scales; S - Scale of type 4, PM SPU 76-20, sample 5919-12a, anterior view; T - scale of type 5 (Moreyella type), PM SPU 76-21, sample 5919-12a, oblique crown view; U - Scale of type 6, PM SPU 76-22, sample 5919-6a, anterior view. Scale bars - 100 $\mu$ m. 


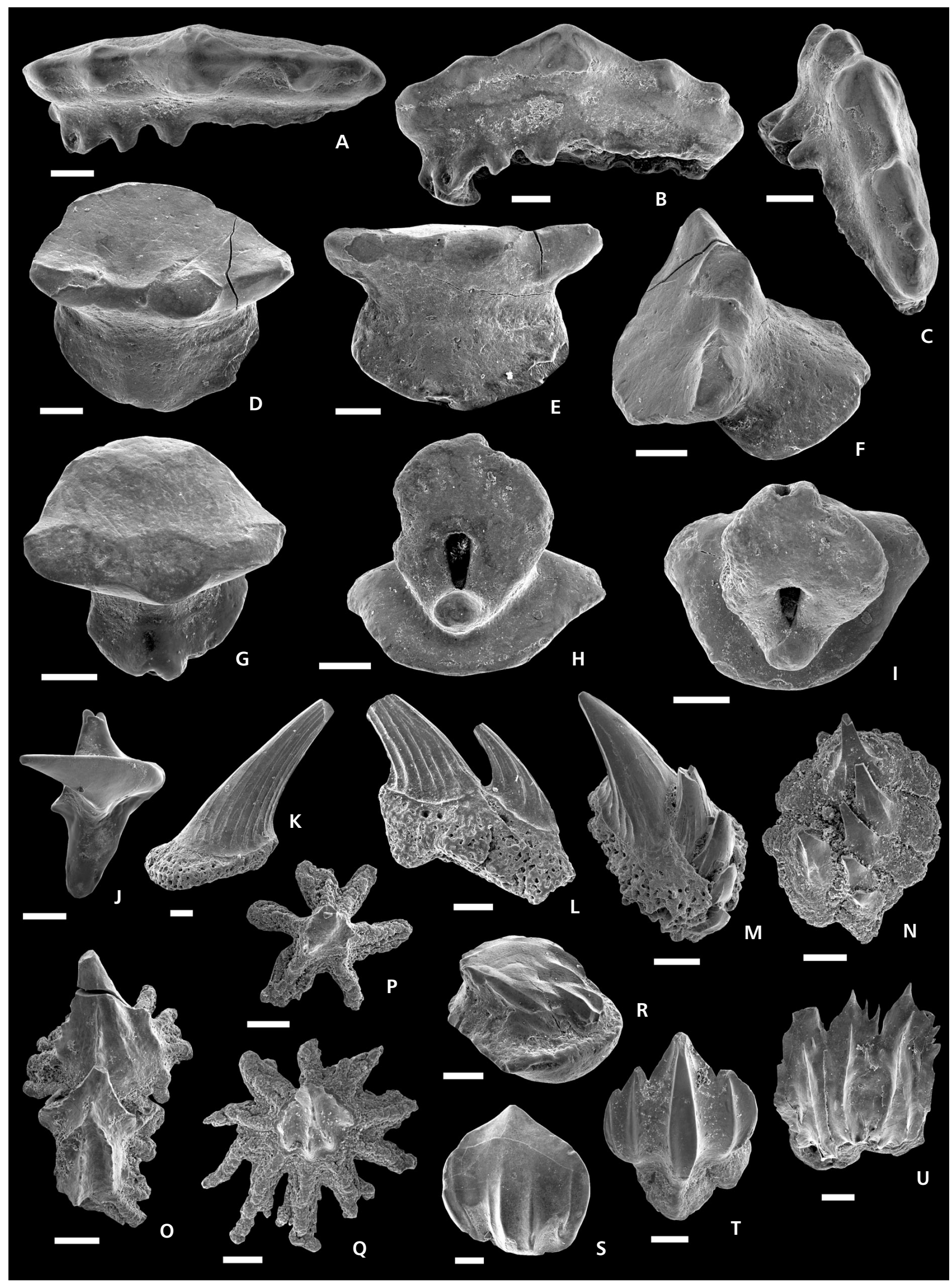


Occurrence. - Late Carboniferous, Moscovian, Brazil; Early Permian, Artinskian, South Urals, Russia; Late Pennsylvanian, Robledo Mountains, New Mexico, USA; Middle Permian, Kazanian, East European Platform, Russia; Roadian, Guadalupe Mountains, Texas, USA.

\section{Chondrichychthyan denticles and scales}

Cephalic spine. - The spine possesses an acuminate, narrow, smooth crown, which is inclined and pointed posteriorly (Fig. 5J). The crown bears a medial crest and the somewhat sloping lateral part terminates in small lateral projections at the base. The spine base has very extended, narrow lateral and small posterior processes, convex external and concave basal surfaces. Cephalic spines are characteristic of hybodontoid sharks (Maisey 1982).

Symmoriiform denticles. - The denticles of symmoriiforms from Mechetlino Quarry are represented by monocuspid, bicuspid and multicuspid types. All denticles may belong to Kungurodus obliquus (Ivanov).

The monocuspid denticles possess a very long, spine-like crown, curved and inclined posteriorly, and flattened laterally (Fig. 5K). The crown is ornamented with distinct straight cristae. The boundary of the crown and base is distinct, and marked by tiny ridge. The base is oval, low, extended anteriorly, porous, and has a slightly convex or flat basal face. Such denticles usually come from the cranial cap or spine-brush complex of several symmoriiforms (see above in Dentition of Cobelodus).

The bicuspid denticles are flattened laterally, and have two separated cusps of large and moderate sizes (Fig. 5L). The cusps are spine-like, inclined posteriorly, and oval in cross section, ornamented with distinct straight cristae, which may coalesce along the anterior edge. The base is convex, porous, with partly fused parts. A narrow groove marks the fusion line of two original denticles.

The multicuspid denticles have a crown comprising five separated, conical cusps arranged in a single spiral row (Fig. 5M). They overlap each other consecutively and increase in size posteriorly. The cusps are incurved, inclined posteriorly, subtriangular in cross section, with distinct lateral carinae separating the slightly convex anterior from the strongly convex posterior surfaces. The anterior surface is almost smooth, with rare tiny, short striae whilst the posterior face is ornamented with distinct, straight cristae. Most cusps (apart from the highest one) one are situated in a deep groove. The denticle base is porous and convex. These denticles ("Stemmatias"-type) are known from buccopharyngeal locations in several genera of symmoriiforms.

Scales. - The scales from Mechetlino Quarry are very diverse in terms of crown and base morphology. Scale type 1 has a large, flat base bearing a complex of spine-like cusps (Fig. 5N). The six cusps (odontodes) are conical, inclined posteriorly, possessing distinct lateral carinae and a few short cristae. The cusps vary in height, from small in anterior part to high in the middle and posterior parts of the scale. The base bears a system of radiating grooves.

The scales of type 2 are characterized by a conical crown, which is inclined posteriorly (Fig. 5O-Q). The crown bears prominent, slightly wavy, serrated ridges separated by deep grooves. The ridges reach the crown apex and are branched at the base. The star-like base is larger than the crown, possesses prominent ridges radiating from the crown base on the external surface. The ridges continue in the long, extended radial processes, which are separated from each other by deep and narrow notches. The processes occasionally terminate in short bifurcations. The number of processes, their length, the depth of the notches in the base as well as the number of crown ridges vary. Two scales are present with partly fused bases (Fig. 5O).

The placoid, almost rhomboid scales of type 3 are protacrodontid in form. They have a low, almost flat, monolithic crown, a narrow neck and a rounded, convex base (Fig. 5R). The crown is smaller than the base, bears curved ridges, and consists of several odontodes closed located and surrounding each other. They are triangular at the anterior edge and elongated, but curved along the lateral margins. The external surface of the crown contains polygonal cell imprints (Ivanov \& Cherepanov 2015). Small foramina open in the posterior surface of the scale neck.

The scales of types 4 and 5 are attributed to euselachians. The scales of type 4 have a drop-like, rounded crown with a pointed posterior edge (Fig. 5S). Distinct ridges are located in the anterior half of the scale. The base is small, with a concave basal surface. The crown in scales of type 5 is a rhomboid, with wide, distinct lateral and medial ridges separated by grooves, and possesses a denticulate posterior edge (Fig. 5T). The central ridge is wide and narrows posteriorly and anteriorly. The scale neck is weakly developed. The base is small, pyramidal, with a concave basal surface. Such scales were described as the formal taxon Moreyella by Gunnell (1933).

The scales of type 6 (Fig. 5U) possess a large, inclined crown with prominent ridges and tiny spines on the external surface. The posterior edge of the crown terminates in elongate, acuminate apices. The small base bears a few large foramina and has a strongly concave basal face.

\section{Discussion}

Relationships of Kungurodus. - Ginter correctly remarked that Cobelodus obliquus should be assigned to a new genus (Ginter et al. 2010), but he supposed that this taxon could not be attributed to the Symmoriiformes because of the pre- 
sence of lateral carinae connecting the cusps together in the crown. The lateral carinae are quite well developed in the cusps of pentacuspid teeth of Kungurodus also possessing a wide base. Some tricuspid teeth have a pronounced carina only in the upper part of the central cusp and weakly developed carinae in the lateral cusps. On the other hand, the teeth of some species of Denaea and especially the teeth of Stethacanthulus possess distinct lateral carinae, which connect the cusps together. Thus, the presence of lateral carinae is not a diagnostic feature for that order. The teeth of Phoebodus usually have lateral carinae but some teeth of Thrinacodus do not possess this character. Most ctenacanthiform teeth possess the carina, but the teeth of Tamioba$t i s$, in contrast, do not. Some genera of xenacanthiforms are characterized by teeth with a well-developed carina but the teeth of some taxa lack it. Clearly, the development of such a carina as well as the type of cusp ornamentation is a variable feature amongst different genera belonging to the same order.

The assignment of Kungurodus to a particular family within the symmoriiforms is questionable. Maisey (2009) redefined two families, Symmoriidae and Falcatidae, based on the morphology of pelvic cartilages. The dental characters provide no additional assistance in defining the family, as noted by Ginter et al. (2010). However, the teeth of Kungurodus show some similarities with the teeth of Denaea, especially in the structure of the base, and these two genera are probably closed related.

Distribution of taxa. - The chondrichthyan assemblage occurring in the Artinskian and Kungurian deposits of Mechetlino Quarry contains isolated teeth of the symmoriiform Kungurodus obliquus, the sphenacanthid euselachian Sphenacanthus sp. and the anachronistid neoselachian Cooleyella amazonensis Duffin, Richter \& Neis, as well as a cephalic spine, symmoriiform denticles and diverse scales. The teeth of Kungurodus, symmoriiform denticles and the scales of type 2 predominate in the assemblage.

Kungurodus obliquus has been found early in the Asselian-Artinskian sequence of the South Urals (Ivanov 2005) and in the Artinskian of the Kazakhstanian Cisurals (Lebedev 2009) but was described also in this paper from the Kungurian. In addition to the Artinskian of the South Urals, species of Sphenacanthus are known from the Viséan to Gzhelian of Great Britain, Spain, Czech Republic, Germany, USA (Iowa), Brazil (Ginter et al. 2010); also from the Artinskian, Early Permian of Brazil (Chahud et al. 2010); from the Kazanian, Middle Permian of the East European Platform, Russia (Ivanov 2012b); from the Capitanian, Middle Permian of Texas, USA (Ivanov et al. 2013). Cooleyella amazonensis occurs in the Moscovian, Late Carboniferous of Brazil (Duffin et al. 1996); Late Pennsylvanian of the Robledo Mountains, New Mexico, USA (Ivanov \& Lucas 2014); Kazanian, Middle Permian of Tatarstan, Vladimir and Kirov regions, East European Platform, Russia (Ivanov 2011); Roadian, Middle Permian of the Guadalupe Mountains, Texas, USA (Ivanov et al. 2012).

Chondrichthyan microremains are not numerous in Mechetlino Quarry in contrast to other localities Early Permian chondrichthyan-containing localities in the South Urals. The chondrichthyan assemblage of the Artinskian of Bashkortostan, South Urals includes symmoriiforms Stethacanthulus decorus (Ivanov), Kungurodus obliquus, Stethacanthus sp., Denaea sp.; the ctenacanthiform Heslerodus sp.; the jalodontid Adamantina foliacea Ivanov; the synechodontid neoselachian Synechodus antiquus Ivanov, anachronistid neoselachians Cooleyella fordi (Duffin \& Ward) and Cooleyella sp. (Ivanov 2005). Stethacanthulus decorus is the dominant species in most Early Permian localities of the Urals but does not occur in the Artinskian-Kungurian relatively deeper-water deposits of the Mechetlino Quarry.

\section{Acknowledgments}

This study was partly supported by the Russian Foundation for Basic Research, project No. 14-04-01507a; by a grant from Saint-Petersburg State University No. 0.38.292.2015 and a PalSIRP-Sepkoski grant. The work was performed according to the Russian Government Program of Competitive Growth of Kazan' Federal University. The author is most grateful to Christopher Duffin (Natural History Museum, London) for the useful comments, text correction and improvement. I would also like to thank Valeriy Chernykh (Institute of Geology and Geochemistry, Uralian Division of the Russian Academy of Sciences, Yekaterinburg) for donation of the material and providing the stratigraphic information; Peter Königshof and Rainer Brocke (Senckenberg Research Institute and Natural History Museum, Frankfurt am Main), Thomas Mörs (Swedish Museum of Natural History, Stockholm), and Lance Grande (Field Museum of Natural History, Chicago) for the opportunity to study the museum collections in their care; Roman Rakitov (Borissiak Paleontological Institute of the Russian Academy of Sciences, Moscow) for assistance during SEM imaging, and Sergey Nilov (Institute of the Earth Sciences, St. Petersburg State University, St. Petersburg) for the microtomographic sections and reconstruction. Scientific researches were performed at the Center for Geo-Environmental Research and Modeling (GEOMODEL) of Research park of St. Petersburg State University. The author thanks Christopher Duffin (Natural History Museum, London) and Michał Ginter (Warsaw University) for their helpful reviews of the manuscript.

\section{References}

Agassiz, L. 1833-43. Recherches sur les Poissons fossiles: 3. Contenant l'Histoire de l'Ordre des Placoüdes. 422 pp. Petitpierre, Neuchâtel. 
Bonaparte, C.L.J. 1838. Selachorum tabula analytica. Nuovi Annali delle Scienze Naturali Bologna 1(2), 195-214.

Chahud, A., Fairchild, T.R. \& Petri, S. 2010. Chondrichthyans from the base of the Irati Formation (Early Permian, Pararna Basin), São Paulo, Brazil. Gondwana Research 18, 528-537. DOI 10.1016/j.gr.2010.01.006

Chernykh, V.V., Chuvashov, B.I., Davydov, V.I. \& Schmitz, M.D. 2012. Mechetlino section: a candidate for the Global Stratotype and Point (GSSP) of the Kungurian Stage (Cisuralian, Lower Permian). Permophiles 56, 21-34.

Chernykh, V.V., Chuvashov, B.I., Davydov, V.I. \& Schmitz, M.D. 2015. Mechetlino section, 5-19. In Nurgaliev, D.K. (ed.) Southern Urals. Deep water successions of the Carboniferous and Permian. A Field Guidebook of XVIII International Congress on Carboniferous and Permian. Pre-Congress A3 Trip. Academy of Sciences of the Republic of Tatarstan Press, Kazan.

Chuvashov, B.I. \& Chernykh, V.V. 2011. Razrez Mechetlino (Yuzhniy Ural) - potentsialniy limitotip nizhney granitsy kungurskogo yarusa [The Mechetlino section (South Urals) a potential limitotype of the lower boundary of the Kungurian Stage]. Doklady Earth Sciences 441(5), 657-660. [in Russian]

Coates, M.I. \& Sequeira, S.E.K. 2001. A new stethacanthid chondrichthyan from the Lower Carboniferous of Bearsden, Scotland. Journal of Vertebrate Paleontology 21, 438-459. DOI 10.1671/0272-4634(2001)021[0438:ANSCFT]2.0.CO;2

Compagno, L.J.V. 1977. Phyletic relationships of living sharks and rays. American Zoologist 17, 303-322. DOI 10.1093/icb/17.2.303

Cope, E.D. 1894. New and little known Paleozoic and Mesozoic fishes. Journal of the Academy of Natural Sciences of Philadelphia 9, 427-448.

Dick, J.R.F. 1998. Sphenacanthus, a Palaeozoic freshwater shark. In Norman, D.B., Milner, A.R. \& Milner, A.C. (eds) A study of fossil vertebrates, Zoological Journal of the Linnean Society 122, 9-25. DOI 10.1111/j.1096-3642.1998.tb02523.x

Duffin, C.J., Richter, M. \& Neis, P.A. 1996. Shark remains from the Late Carboniferous of the Amazon Basin, Brazil. Neues Jahrbuch für Geologie und Paläontologie, Monatshefte 1996(4), 232-256.

DufFIN, C.J. \& WARD, D.J. 1983. Neoselachian shark teeth from the Lower Carboniferous of Britain and the Lower Permian of the USA. Palaeontology 26(1), 93-110.

Fournier, G. \& Pruvost, P. 1928. Déscriptions des poissons élasmobranches du Marbre noir de Denée. Mémoires de la Société Géologique du Nord 9, 1-23.

Ginter, M., Hampe, O. \& Duffin, C. J. 2010. Chondrichthyes Paleozoic Elasmobranchii: Teeth, 1-168. In SchUltze, H.P. (ed.) Handbook of Palaeoichthyology, v. 3D. Verlag Dr. Friedrich Pfeil, München.

GunNeLL, F.M. 1933. Conodonts and fish remains from the Cherokee, Kansas City, and Wabaunsee groups of Missouri and Kansas. Journal of Paleontology 7, 261-297.

HAY, O.P. 1902. Bibliography and catalogue of the fossil vertebrata of North America. US Geological Survey Bulletin 179, 1-868.

HuXLEY, T.H. 1880. On the application of the laws of evolution to the arrangement of the Vertebrata, and more particularly of the
Mammalia. Proceedings of the Zoological Society of London $1880,649-662$.

Ivanov, A. 2005. Early Permian chondrichthyans of the Middle and South Urals. Revista Brasileira de Paleontologia 8(2), 127-138. DOI 10.4072/rbp.2005.2.05

Ivanov, A. 2011. Permskie anachronistidnye akuly VostochnoEvropeyskoy platformy i Urala [Permian anachronistid sharks of the East European Platform and Urals], 17-19. In SHISHKin, M.A., Golubev, V.K., Novikov, I.V. \& Sennikov, A.G. (eds) Pozvonochnye paleozoya $i$ mezozoya Evrazii: evolutsiya, smena soobschestv, tafonomiya i paleobiogeografiya. PIN RAN, Moscow. [in Russian]

Ivanov, A.O. 2012a. [Ichthyofauna from the Artinskian and Kungurian deposits of the South Urals], 30. In NAUGOLNYKH, S.V. (ed.) Paleontologiya $i$ evolutsiya bioraznoobraziya $v$ istorii Zemli. Geos, Moscow. [in Russian]

Ivanov, A.O. 2012b. Elasmobranchs from the Kazanian Stage of European Russia, 101-104. In ZhamoidA, A.I. (ed.) Paleozoy Rossii: Regionalnaya Stratigrafiya, Paleontologiya, Geo$i$ Biosobytiya. VSEGEI, St. Petersburg. [in Russian]

Ivanov, A.O. \& Cherepanov, G.O. 2015. Imprints of cell structures on the exoskeletal elements of the Palaeozoic fishes, 152-154. In Bogdanova, T.N., Bugrova, E.M., Danilov, I.G., Evdokimova, I.O., Ivanov, A.O., Kossovaya, O.L., Oshurkova, M.V., Popov, E.V., Raevskaya, E.G., SuyarKova, A.A. \& Tolmacheva, T.Yu. (eds) Sovremennye problemy paleontologii; Materialy LXI Sessii Paleontologicheskogo Obschestva. ElekSis, St. Petersburg. [in Russian]

IvANov, A.O. \& DeRYCKE, C. 2005. Viséan elasmobranchs of Belgium. Ichthyolith Issues, Special Publication 9, 13-17.

IvanOv, A.O. \& LuCAS, S.G. 2014. Fish assemblage from the Late Pennsylvanian of the Robledo Mountains, New Mexico, 2. In Abstracts of the GSA South-Central Section Meeting, Fayetteville, Arkansas, USA.

Ivanov, A.O., Nestell, M.K. \& Nestell, G.P. 2012. A diverse Roadian (Guadalupian, Middle Permian) fish assemblage from the Cutoff Formation, Guadalupe Mountains, West Texas, 3-4. In Abstracts of the GSA South-Central Section Meeting, Alpine, Texas, USA.

Ivanov, A.O., Nestell, G.P. \& Nestell, M.K. 2013. Fish assemblage from the Capitanian (Middle Permian) of the Apache Mountains, West Texas, USA. New Mexico Museum of Natural History and Science, Bulletin 60, 152-160.

Ivanov, A.O., Nestell, M.K. \& Nestell, G.P. 2015. Middle Permian fish microremains from the Early Capitanian of the Guadalupe Mountains, West Texas, USA. Micropaleontology 61(4-5), 301-312.

LeBEDEV, O.A. 2009. A new specimen of Helicoprion Karpinsky, 1899 from Kazakhstanian Cisurals and a new reconstruction of its tooth whorl position and function. Acta Zoologica 90(Suppl. 1), 171-182.

DOI 10.1111/j.1463-6395.2008.00353.x

Lund, R. 1974. Stethacanthus altonensis (Elasmobranchii) from the Bear Gulch Limestone of Montana. Annals of Carnegie Museum 45(8), 161-178.

Lund, R. 1984. Spines of the Stethacanthidae (Chondrichthyes), with a description of a new genus from the Mississippian Bear Gulch Limestone. Geobios 17(3), 281-295.

DOI 10.1016/S0016-6995(84)80095-9 
Lund, R. 1985. The morphology of Falcatus falcatus (St. John and Worthen), a Mississippian stethacanthid chondrichthyan from the Bear Gulch Limestone of Montana. Journal of Vertebrate Paleontology 5, 1-19. DOI 10.1080/02724634.1985.10011842

Lund, R. 1986. On Damocles serratus, nov. gen. et sp. (Elasmobranchii, Cladodontida) from the Upper Mississippian Bear Gulch Limestone of Montana. Journal of Vertebrate Paleontology 6, 12-19.

DOI 10.1080/02724634.1986.10011594

MAISEY, J.G. 1982. The anatomy and interrelationships of Mesozoic hybodont sharks. American Museum Novitates 2724, 1-48.

MaIsey, J.G. 2007. The braincase in Paleozoic symmoriiform and cladoselachian sharks. Bulletin of the American Museum of Natural History 307, 1-122.

DOI 10.1206/0003-0090(2007)307[1:TBIPSA]2.0.CO;2

MaIsey, J.G. 2009. The spine-brush complex in symmoriiform sharks (Chondrichthyes; Symmoriiformes), with comments on dorsal fin modularity. Journal of Vertebrate Paleontology 29(1), 14-24. DOI 10.1671/039.029.0130
SolER-GiJón, R. 1997. Euselachian sharks from the Late Carboniferous of the Puertollano basin, Spain: biostratigraphic and palaeoenvironmental implications. Modern Geology 21, 137-169.

Williams, M.E. 1985. The 'cladodont level' sharks of the Pennsylvanian black shales of central North America. Palaeontographica A 190(3/6), 83-158.

ZANGERL, R. 1973. Interrelationships of early chondrichthyans. Zoological Journal of the Linnean Society of London 53(Supplement 1), 1-14.

ZANGERL, R. 1981. Paleozoic Elasmobranchii, 1-115. In Schultze, H.P. (ed.) Handbook of Paleoichthyology, v. $3 A$. Gustav Fischer, Stuttgart - New York.

ZANGERL, R. \& CASE, G.R. 1976. Cobelodus aculeatus (Cope), an anacanthous shark from Pennsylvanian black shales of North America. Palaeontographica Abteilung A 154(4-6), 107-157.

ZIDEK, J. 1992. Late Pennsylvanian Chondrichthyes, Acanthodii, and deep-bodied Actinopterygii from the Kiney Quarry, Manzanita Mountains, New Mexico. New Mexico Bureau of Mines and Mineral Resources Bulletin 138, 145-182. 